\title{
Research on Strategic Human Resource Management and Its Theoretical Foundation
}

\author{
Zhang Jing
}

Hainan University

737371435@qq.com

\begin{abstract}
Keywords: Strategic Human Resource Management, Human Capital; Human Resource Management Practice; Firm Performance
\end{abstract}

\begin{abstract}
With the development of strategic management, human resources management has been raised to strategic position1There were different definitions towards strategic human resources management (SHRM)1However, all of the definitions come to the same key point that HR practices are quite important to organization performance1Many scholars studied respectively on the effect of HRM on organization performance according to different theories, such as resource-based theory, human capital theory, behavior theory, general system theory, transaction and agent theory1This paper indicates that the main difference of these studies lies in the different impact system of HRM practices on organization performance and implies the future research directions
\end{abstract}

\section{Introduction}

Chinese listed companies prefer equity financing, so their investment spending depend largely on its achievement of external financing needs, which is consistent with the hypothesis of financing constraints. Listed companies generally face financing constraints, investment spending is more dependent on its share of financing rather than debt financing. This feature is significantly different from listed companies in developed countries. Meanwhile, with respect to large companies, small companies great volatility in investment spending. From the different periods of different financing constraint conditions caused by corporate balance sheet channel to deal with the impact of business investment. Explore the impact of changes in the investment of Chinese enterprises in the economic mechanism in two phases before and after the crisis situation.

\section{Research Hypothesis}

Hypothesis. Balance sheet channel effect has a less significant impact on the company which has a low interest coverage ratio. And compared with the company with high interest coverage ratio, this effect has a smaller correlation with investments. With the growing trend of financial globalization, financial crisis has radiated a wider range. In the course of the financial crisis, the balance sheet channel effect amplifies the volatility in the balance sheet variables, thereby amplifying the macro to the micro-business impact. And this impact is more pronounced the willingness to invest in foreign investment compared with the impact before the crisis. This paper attempts to study this particular capital markets in China, and to explore whether the balance sheet channel effect for business investment is different from Western developed economies. At the same time we explore the specific effects of changes in corporate investment sentiment after the crisis.

Hypothesis. The companies with low interest coverage have a significant stocks balance sheet channel effect before the crisis; and after the crisis, due to external financing is limited, thus is not significantly; The companies with high interest coverage ratio has a significant balance sheet channel effect around the crisis; while after the crisis, because the crisis has brought tremendous negative impact; let the channels effect has a greater impact for enterprises investment and the relevance has been enhanced. 


\section{Research Design}

Variables design. Based on the theory above, in order to overcome the deficiencies of the existing empirical research on the variables selected, this paper on the basis of availability of data, we correct the standard model and select the following indicators as the original variable.

Table 1 The Variable definitions

\begin{tabular}{|c|c|c|}
\hline Symbol & Nature & Variable definitions \\
\hline $\mathrm{I} / \mathrm{K}$ & $\begin{array}{c}\text { Interpreted } \\
\text { variables }\end{array}$ & (Net investment in fixed assets + Net in progress + Net long-term investments) \\
Capital stock
\end{tabular}

The sample selection and data process. In this paper, there are 2005-2010 Shanghai Stock Exchange listed companies as the research object, take the following criteria in the sample selection:

1. Sample companies are listed before January 1, 2003 and continue to trade in 2010;

2. Excluding ST companies, such enterprises have large amplitude fluctuations in results, the data obtained are not comparable;

3. Excluding financial companies, there are significant differences in the accounting system adopted by such companies with other companies, and in accordance with the Commission Industry Classification Standard, the industry classification of the remaining differences in order to control the industry;

4. Excluding incomplete data and companies anomalies data, and then select from a valid sample of companies we finally get 100 companies.

The model selection. According to the previous theoretical analysis, the results of a comprehensive study of the existing literature in this paper, the use of traditional linear regression analysis, taking full account of the latest theoretical challenges raised by traditional research, select the corrected model as an empirical analysis model.

$$
\mathrm{UK}=\mathrm{aP}(\mathrm{A}-\mathrm{D}) / \mathrm{K}+\mathrm{bQ}+\mathrm{cS} / \mathrm{K}+\mathrm{dCF} / \mathrm{K} \text { jr } £(1)
$$

On the basis of the investment cash flow model, analysis model balance sheet channel effect if the corresponding variable, total assets fluctuate Select this article with Wang Chen Xue (2010) Changes in asset prices caused as a measure of the balance sheet channel effect. Measure of investment opportunities in the choice of Tobin Q, S ratio of sales revenue and capital stock K simultaneously measure two variables.

\section{An Empirical Analysis of Listed Companies}

Descriptive statistics. This article will be 98 samples by the interest coverage ratio greater than 5 as high interest coverage group is financing constraints (CR) and the interest coverage ratio less than 5 as CR high, which means that low interest representing a multiple of the company's financing constraints high. There are 64 high interest companies and 34 low interest companies.

Table 2 reports the descriptive statistics for each variable during 2005-2007. As can be seen from the table, in 2005-2007, the balance sheet channel effect of low interest rates mean multiple companies for 3.162, while the company's high interest coverage indicators mean 19.265, indicating a multiple of the net assets of the company's high interest rates are more vulnerable to stock market price fluctuations. Second, low interest, "the company's cash flow and the mean maximum value is 0.180 and 0.044 , respectively, were higher than the company's interest cover 0.000 and raw 0 , indicating that compared with the latter, the former under conditions of limited external financing, 
which investment rely more on internal cash flow. Finally, the maximum investment in a low interest coverage group companies / total assets index, mean, standard deviation, respectively $1.032,0.444,45$, slightly high interest cover enterprise $0.998,0.428,0.243$, indicating multiple companies with low interest compared assets 1 sheet channel effect on high- interest financing constraints affect multiple companies stronger, more likely to cause external financing is limited, so that the high interest coverage multiple companies with low interest subject to a considerable degree of financing constraints, ultimately limiting the enterprise investment.

Table 2 The Descriptive statistics before crisis

\begin{tabular}{|c|c|c|c|c|c|c|c|c|c|}
\hline \multicolumn{10}{|c|}{ Descriptive Statistics (2005-2007) } \\
\hline \multirow[b]{2}{*}{ Variable } & \multirow[b]{2}{*}{$\mathrm{N}$} & \multicolumn{2}{|c|}{ Min } & \multicolumn{2}{|c|}{ Max } & \multicolumn{2}{|c|}{ Mean } & \multicolumn{2}{|c|}{ Standard deviation } \\
\hline & & CR High & CR Low & CR High & CR Low & CR High & CR Low & CR High & CR Low \\
\hline $\mathrm{I} / \mathrm{K}$ & 98 & 0.062 & 0.057 & 1.032 & 0.998 & 0.444 & 0.428 & 0.245 & 0.243 \\
\hline $\mathrm{P}^{*}(\mathrm{~A}-\mathrm{D}) / \mathrm{K}$ & 98 & -10.383 & -815.416 & 21.483 & 21.261 & 3.162 & -19.265 & 4.401 & 141.271 \\
\hline Q & 98 & 0.199 & 0.135 & 7.936 & 320.518 & 0.799 & 11.439 & 1.069 & 55.355 \\
\hline $\mathrm{S} / \mathrm{K}$ & 98 & 0.007 & 0.008 & 32.918 & 77.311 & 2.477 & 3.985 & 5.679 & 13.588 \\
\hline $\mathrm{CF} / \mathrm{K}$ & 98 & -0.220 & 0.000 & 0.180 & 0.000 & 0.044 & 0.040 & 0.068 & 0.0841 \\
\hline
\end{tabular}

2008-2010 descriptive statistics of the variables are shown in Table 3, from which we can see that in this period, the average company's low interest coverage ratio was 3.350 , and the mean high interest coverage indicator is -0.864 , indicating that the crisis period, the net assets of the company by the low interest cover fluctuations in stock market prices slightly higher than the high interest coverage companies. In addition, low interest rates and high interest coverage multiple of the company's cash flow mean is 0.064 and 1.460, respectively, indicating that the former under conditions of limited external financing, internal cash accumulation was greatly constrained. Finally, the average investment in the company's low interest coverage ratio / total assets index was 0.343 , slightly higher than the high interest cover enterprises 0.291 , showing external financing constraints will indeed limit the investment behavior of enterprises.

Table 3 The Descriptive statistics after crisis

\begin{tabular}{|c|c|c|c|c|c|c|c|c|c|}
\hline \multicolumn{10}{|c|}{ Descriptive Statistics (2008-2010) } \\
\hline & & \multicolumn{2}{|c|}{ Min } & \multicolumn{2}{|c|}{ Max } & \multicolumn{2}{|c|}{ Mean } & \multicolumn{2}{|c|}{ Standard deviation } \\
\hline Variable & $\mathrm{N}$ & CR High & CR Low & CR High & CR Low & CR High & CR Low & CR High & CR Low \\
\hline $\mathrm{I} / \mathrm{K}$ & 98 & 0.002 & 0.003 & 1.593 & 2.102 & 0.343 & 0.291 & 0.296 & 0.379 \\
\hline $\mathrm{P} *(\mathrm{~A}-\mathrm{D}) / \mathrm{K}$ & 98 & -13.833 & -238.429 & 29.745 & 25.231 & 3.350 & -0.864 & 5.325 & 41.567 \\
\hline $\mathrm{Q}$ & 98 & 0.206 & 0.070 & 12.040 & 46.608 & 0.880 & 1.812 & 1.466 & 7.797 \\
\hline $\mathrm{S} / \mathrm{K}$ & 98 & 0.009 & 0.000 & 24.901 & 83.753 & 2.947 & 6.315 & 5.469 & 17.368 \\
\hline $\mathrm{CF} / \mathrm{K}$ & 98 & -0.090 & 0.000 & 0.800 & 50.000 & 0.064 & 1.460 & 0.112 & 8.524 \\
\hline
\end{tabular}

Table 4 shows the descriptive statistics balance sheet channel effect indicators for both periods 2005-2007 and 2008-2010. For higher corporate financing constraints, the maximum value of the index during the period 2008-2010, the mean and standard deviation are 29.745,3.350 and 5.325, respectively, were more than $21.483,3.162,4.401$ in $2005-2007$ period. While lower corporate financing constraints, the average of the index in the two periods is -19.265 and -0.864 , respectively, are negative. And the value in the 2008-2010 is much higher than in 2005-2007, and then show that the greater impact of lower corporate financing constraints by the financial crisis. Meanwhile, due to lower corporate financing constraints before the economic crisis easier to external financing, coupled with the preference of corporate equity financing, net assets are greater influence stock price fluctuations. The asset price fluctuations caused by economic crisis, resulting in its external investment funds rely on previously constrained, so invest more severe atrophy. 
Table 4 The descriptive statistics in sheet channel effect indicators

\begin{tabular}{|c|c|c|c|c|c|c|c|}
\hline \multicolumn{7}{|c|}{ Descriptive Statistics $(\mathrm{P} \neq$ 丰 $(\mathrm{A}-\mathrm{D}) / \mathrm{K})$} \\
\hline \multirow{2}{*}{ Variable } & \multirow{2}{*}{$\mathrm{N}$} & \multicolumn{3}{|c|}{ Max } & \multicolumn{2}{c|}{ Mean } & \multicolumn{2}{c|}{ Standard deviation } \\
\cline { 3 - 8 } & & CR High & CR Low & CR High & CR Low & CR High & CR Low \\
\hline $2005-2007$ & 98 & 21.483 & 21.261 & 3.162 & -19.265 & 4.401 & 141.271 \\
\hline $2008-2010$ & 98 & 29.745 & 25.231 & 3.350 & -0.864 & 5.325 & 41.567 \\
\hline
\end{tabular}

\section{Regression results}

Table 5 The multivariate linear regression analysis results

\begin{tabular}{|c|c|c|c|c|c|c|c|c|}
\hline & \multicolumn{4}{|c|}{ Low multiple of interest safeguard group } & \multicolumn{4}{|c|}{ High multiple of interest safeguard group } \\
\hline & \multicolumn{2}{|c|}{$2005-2007$} & \multicolumn{2}{|c|}{$2008-2010$} & \multicolumn{2}{|c|}{$2005-2007$} & \multicolumn{2}{|c|}{$2008-2010$} \\
\hline Variable & & (p) & & $(p)$ & & $(p)$ & & (p) \\
\hline $\mathrm{P} *(\mathrm{~A}-\mathrm{D}) / \mathrm{K}$ & $0.035^{* * *}$ & 0.000 & 0.02 & 0.033 & $0.013 * *$ & 0.005 & $0.028 * * *$ & 0.000 \\
\hline $\mathrm{K}$ & -5.081 & & -2.179 & & -3.001 & & -6.155 & \\
\hline \multirow{3}{*}{ Q } & $0.133 *$ & 0.000 & $0.078 * * *$ & 0. 009 & $0.033 * *$ & 0.004 & $0.144 * * *$ & 0.000 \\
\hline & -4.873 & & -2.683 & & -3.073 & & -6.238 & \\
\hline & 0 & 0.976 & 0.016 & 0.08 & 0.003 & 0.519 & -0.003 & 0.285 \\
\hline $\mathrm{S} / \mathrm{K}$ & $(-0.03)$ & & -1.779 & & -0.653 & & $(-1.088)$ & \\
\hline \multirow[b]{2}{*}{$\mathrm{CF} / \mathrm{K}$} & $3.301 * * *$ & 0.000 & 0.476 & 0.244 & $2.412 * *$ & 0.002 & $0.039 * * *$ & 0.000 \\
\hline & -7.21 & & -1.176 & & -3.388 & & -9.223 & \\
\hline $\mathrm{F}$ & 39.447 & 0.000 & 8.635 & 0.000 & 8.68 & 0.000 & 36.938 & 0.000 \\
\hline $\mathbb{R}^{2}$ & 0.725 & & 0.365 & & 0.536 & & 0.827 & \\
\hline$\triangle \mathbb{R}^{2}$ & 0.706 & & 0.323 & & 0.475 & & 0.804 & \\
\hline
\end{tabular}

Note: () as the $\mathrm{t}$ value, $\mathrm{P}$ is sig value, $* * *, * *, *$, respectively $1 \%, 5 \%$ and $10 \%$ significance level

Table 5 reports the regression results business investment. The return of the sample, according to the results of the adjusted $\mathrm{R} 2$ of $0.706,0.323,0.475,0.323$, shows that the explanation of a model to be explained variables had a very good explanation, and the fit of the overall good, F statistics are significant at the $1 \%$ level. Table 5 shows the return of the balance sheet channel effect as a result, from which we can find that the balance sheet channel effect of two groups of companies were significantly positive regression coefficient, shows that the enterprise investment channels and balance sheet effect before significant positive correlation relationship.

In addition, the low interest multiples of regression coefficients of 0.035 , more than high interest ratio of 0.013 , shows that before the financial crisis, low interest multiples of corporate investment under the influence of the balance sheet channel effect is bigger, the higher the financing constraints, the greater the influence of the balance sheet channel effect on enterprises investment, hypothesis 1 is not established, the return of the period 2008-2010, according to the results of multiple low interest of the company's balance sheet channel effect commend index regression coefficient is 0.02 , while the multiple of high interest rates of the variable regression coefficient is 0.028 , the regression coefficients are very significant. Shows that after the financial crisis, the lower the interest multiples of corporate investment for its investment rely on internal cash flow is affected by the weak balance sheet channel effect, and high interest because of its multiple company from external equity financing to bank loan financing channel and balance-sheet channel effect is still obvious, but due to the equity financing more affected by the stock price volatility caused by the net assets, and our bank loans for financing constraints, low enterprises are relatively stable sources of finance, so the variable coefficient by 0.035 to 0.028 . With the expectations hypothesis 2 multiples of low interest rates before the crisis by companies have been more significant balance sheet channel effect, and after the crisis with high interest rates a multiple hypothesis 2 company balance sheet channel effect is stronger, hypothesis 2 is not fully established. 


\section{Conclusions}

Our results show that in the period of crisis, high interest coverage are subject to greater business investment) impact, but also significantly related investments and balance sheet channel effects. However, companies with low interest coverage, balance sheet channel effects in crisis "of being weak and not significant. One reason may be due to the existing literature abroad, especially in the theoretical literature analysis phase will emphasize market environment and institutional environment, and China's particularity is mainly reflected in two aspects of corporate financing structure and investment behavior of Chinese enterprises for financing SMEs Not only in terms of the need to pay higher costs and face higher threshold, so the high interest coverage ratio to measure low while corporate financing constraints, but also a measure of the ease of corporate external financing.

\section{References}

[1] Chu-Ping C, Vijverberg: Journal of Macroeconomics, Vol. 26 (2004) No 7, p. 101-129

[2] Suvadee Rungsomboon: Asian Economic Journal, Vol. 3(2005) No 6, p.335-356

[3] Charles Nolan, Christoph Thoenissen: Economics, Vol. 56(2009) No 4, p. 596-604

[4] Marco Antonio F, H.Cavalcanti: Journal of Macroeconomics, Vol. 32(2010) No 3, p.118-144

[5] Francois Hermet: Economics Bulletin, Vol. 12(2003) No 12, p.11-12 